UDC: $636: 629.056 .84$

COBISS.SR-ID: 212204812

Acta Agriculturae Serbica, Vol. XIX, 38(2014) 115-122



\title{
SMS shepherd
}

\author{
Uroš Pešović, Slađana Đurašević \\ Faculty of technical sciences Čačak, University of Kraguejvac, Serbia \\ Dušan Marković \\ Faculty of agronomy Čačak, University of Kraguejvac, Serbia
}

\begin{abstract}
SMS shepherd is a device designed to locate objects in the open spaces. Device is primarily intended for locating domestic and wild animals, but can be used in locating people, vehicles, remote control models and other object which may change its position. SMS shepherd is small size, battery power mobile device, which can be easily mounted on animals or other objects in order to track. Device can be used in several modes, to locate objects that have left the predefined area or locate objects in free space compared to a predefined reference points. The device uses SMS messages for interaction with the user, so user doesn't need to have computer skills or internet access to use it. The device requires mobile network coverage for its work. Given that the coverage of the territory of the Republic of Serbian mobile network is relatively high are provided good conditions for the use of such devices in practice.
\end{abstract}

Key words: SMS, shepherd, GPS, mobile, cattle. 


\section{Introduction}

Pasture-based livestock farming is one of the bases of sustainable food production. In such environment, animals are able to eat nutritious grass and other plants that their bodies are adapted to digest. Such kind of livestock farming doesn't require huge expenses for production of animal food, such as on regular farms. In addition, pasture-based livestock farming dramatically improves the welfare of farm animals and also helps in reducing environmental impact. Pasture-based farming is crucial for production of pure organic products which that are tastier and more nutritious than foods produced on regular farms. In addition market demand for organic products is rapidly increasing and prices are higher than products form regular farms. Such kind of farming is ideal for small family farms, since in regular farm production on small farms cannot be competitive with large cooperate farms.

Animals in pasture-based livestock farming are usually located in fenced pastures or allowed to roam freely in pastures and forests (Butler et al. 2004. and Ungar et al. 2005). Such kind of farming requires frequent or permanent livestock monitoring by shepherds, which requiring a lot of man hours, leading to increasing expenses in production, especially for small family farms. In order to reduce cost, animals could be left without shepherd monitoring, rounded and returned to stables in the evening. Without monitoring, cattle can breach pasture fences and roam far away in any direction, which makes very hard to locate them visually in the evening when owners plan to return them to stables. The simplest way of localization of the cattle or herd is by attaching the cow bell to dominant animal and to follow the sound in order to locate them. Such localization technique has small range and can be affected by noise from the wind or rain which can make localization impossible. In the evening cattle tend to become stationary, bell will not produce any sound, which also complicates localization. Cattle can be localized using radio localization by carrying small radio transmitters which transmit radio beacons. Owner can locate cattle using directed antenna by determining bearing from which radio beacon is coming. By using two different bearing observations, owner can pinpoint cattle location by triangulation. This method is not practical because it requires sufficient technical knowledge of owner. Radio transceiver needs to operate continuously which can result in high energy consumption and shortened battery life of transceiver. Radio transmission also requires existence of line of sight with receiver, in order to receive beacons. Introduction of handheld localization devices based on Global Positioning System (GPS) enabled precise pinpoint localization, wherever on globe with accuracy of several meters, no matter of weather conditions. Such devices can also be used in livestock monitoring, in order to 
inform owners that livestock has breached pasture fence, or to help owners to locate livestock in open spaces. Modern GPS transceivers have small dimensions and small power consumption and they locate object anywhere on Earth. When combined with mobile network for transmitting location information using SMS service, these devices can operate anywhere no matter of distance from cattle to owner. By using SMS messages user doesn't need to have technical skills or internet access in order to locate cattle herd. This paper represent prototype of such system, which can be successfully used for cattle monitoring for months in open field.

\section{Results and Discussion}

GPS represents the only currently operational global satellite positioning system composed from 24 satellites in orbit around Earth. GPS satellites use synchronized high precision atomic clocks to transmit messages with current timestamp. When receiver on Earth receives signals from at least three satellites, it determines the distance to each satellite by using time difference of message timestamp. Using triangulation, receiver can compute exact position on Earth. By using signals from three satellites, less accurate two-dimensional (2D) fix is acquired, which determines geographical longitude and latitude. By using signals from four satellites, more accurate three-dimensional (3D) fix is acquired, which provides altitude from the sea level. Up to 12 signals from different satellites can be received which provides substantial accuracy of several meters. GPS navigation can work in any part of the globe, during day and night in all weather conditions. Thanks to advances in circuit integration, GPS receivers became much smaller, so today they became integral part of any smart phone or handheld device.

SMS Shepherd device is based on Telit GM862-GPS module which includes SiRFstarIII ${ }^{\mathrm{TM}}$ single chip GPS receiver. This GPS receiver can process up to 20 signals from different satellites. It uses active antenna which enables high sensitivity even for indoor reception and accuracy up to 2.5 meters in outdoor applications. Device has small power consumption of $75 \mathrm{~mA}$ including consumption of active antenna and fast response time; it can acquire hot start 3D fix in under 3 seconds, or cold start 3D fix under 35s. Telit Module GM862-GPS is quad-band GSM/GPRS transceiver which has all capabilities equivalent to smart mobile phone. It has small dimensions of 44 by $44 \mathrm{~mm}$ with height of $7 \mathrm{~mm}$. Module is powered by single cell $3.6 \mathrm{~V}$ lithium-ion battery and has small power consumption $(26 \mathrm{uA}$ in sleep, $2.6 \mathrm{~mA}$ in idle mode and $200 \mathrm{~mA}$ in operation mode). Module includes push-push SIM holder, SIM phonebook and real time clock with alarm. Beside basic audio and SMS capabilities, module has integrated TCP/IP Stack which can be used for Internet access through GPRS 
protocol. Module has 13 digital input/outputs and one analog input, as well as UART, $\mathrm{I}^{2} \mathrm{C}$ and SPI digital bus interface, which can be used for attaching sensors and actuators with module. Module can work as modem, controlled by external microcontroller or can work by itself, controlled by python script which is programmed into modules internal memory. Python script is written on computer and programmed to module via UART interface, or can be updated over-the-air software update. Module offers $1.9 \mathrm{MB}$ of non-volatile FLASH memory for program scripts and data log files, as well as $1.2 \mathrm{MB}$ of RAM memory. Size of Telit module relative to coin is shown in Figure 1. (Telit 2009)

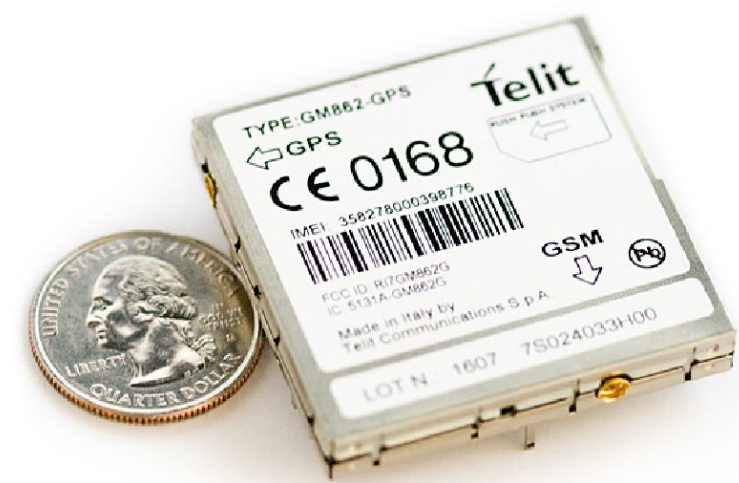

Figure 1. Size of Telit GM862-GPS module relative to coin

SMS Shepherd device is powered by rechargeable $3.6 \mathrm{~V} 2400 \mathrm{mAh}$ lithiumion battery, which is housed inside device. Battery provides few days of autonomy and can be recharged using voltage adapter during night, when cattle are in stable. Device has active GSM/GPS antenna which is located inside device housing. Dimensions of SMS Shepherd device are $110 \mathrm{~mm}$ in length, $90 \mathrm{~mm}$ width and $35 \mathrm{~mm}$ height, with weight of device of about 300 grams. Interior of device and mounting on cow are shown in Figure 2.
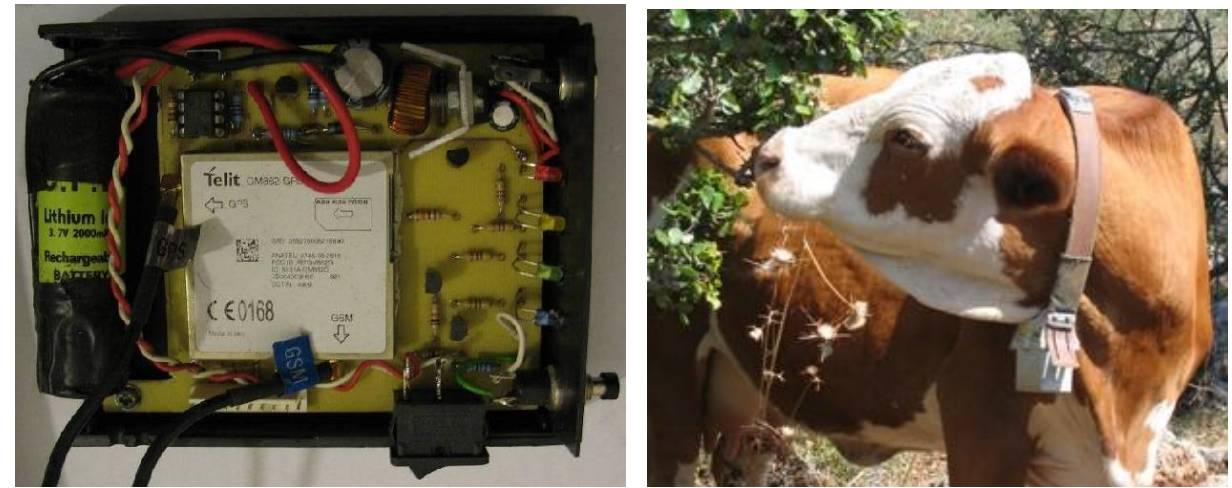

Figure 2. Interior of SMS Shepherd device and device attached to cow 
SMS shepherd device can work in two modes of operation which is selected by user. It can be used for localization of animals inside fenced pastures, or it can be used for localization of animals which are left to roam freely in open space. In both operating modes device is able to inform the user when battery is depleted with appropriate SMS message which also contains device GPS location.

When used for fenced pastures, user must first define fence perimeter, by caring device around the pasture fence. Pasture fence is defined as complex polygon, were points of polygon are geographic coordinates, acquired by GPS, which are saved in device when user presses certain button on device. When user completes definition of polygon, it switches the device in operating mode and device sends SMS message which informs user about newly defined polygon. Polygon must have at least three points and most 30 points in order to limit amount of computational complexity. When polygon is defined, user attaches device around the neck of dominant animal in herd, using appropriate belt, which holds device firmly. When attached to animal, device periodically acquires GPS coordinates in order to determine is the current device position relative to predefined polygon. The simplest way of finding whether the device is inside or outside a polygon is to test how many times a ray, starting from the point representing device location and going in any fixed direction, intersects the edges of the polygon. If the number of intersections is an odd number the device is inside the polygon; if the number of intersections is an even the device is outside of polygon (Wikipedia 2014). This rule applies no matter of the complexity of the polygon, even applies if polygon is hollow, shown in Figure 3.

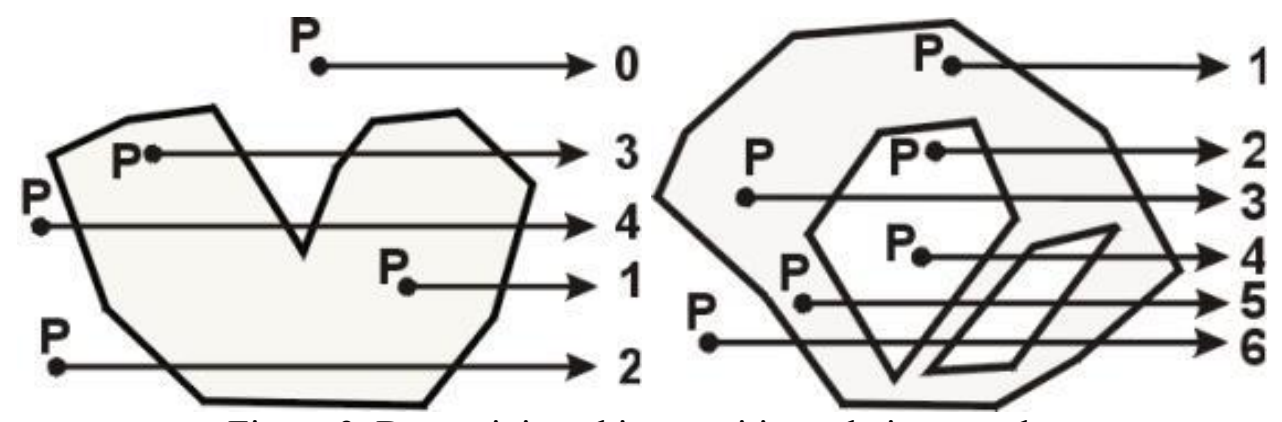

Figure 3. Determining object position relative to polygon

GPS location can change due interferences even if the object is stationary, it's necessary to prevent occurrence of false alarms when device is very close to the fence boundary. GPS offers horizontal dilution of precision parameter, which can be used to eliminate false alarms when GPS location is accidently determined to be outside the polygon, even if device physical position is inside polygon. When device discovers that the dominant animal breached the pasture fence, it starts to transmit SMS messages to user with information about heading 
and distance between device and center of the polygon. SMS messages are transmitted in 5 minutes intervals.

Device can be also be used for localization of herd which roams in free space. For ease of localization, up to 30 predetermined reference points, known to user, are programmed into device. Each point is defined by its geographical latitude and longitude and it name. In this operation mode, device is always in low power mode, conserving battery energy. When user sends SMS query message in predefined format, device enters operating mode and tries to acquire GPS location. When appropriate GPS fix is acquired, device calculates distance to all reference points and selects reference point which is closest to the device. Device then determines bearing to determine cardinal direction in which device is pointed relative to closest reference point. Then device replies to user with SMS message with information about distance to closest reference point, name of closest reference point and cardinal direction relative to closest reference point. In order to provide exact location, device also adds geographical latitude and longitude to SMS message. Received coordinates can be entered in Google Maps to find exact location of device as shown in Figure 4.

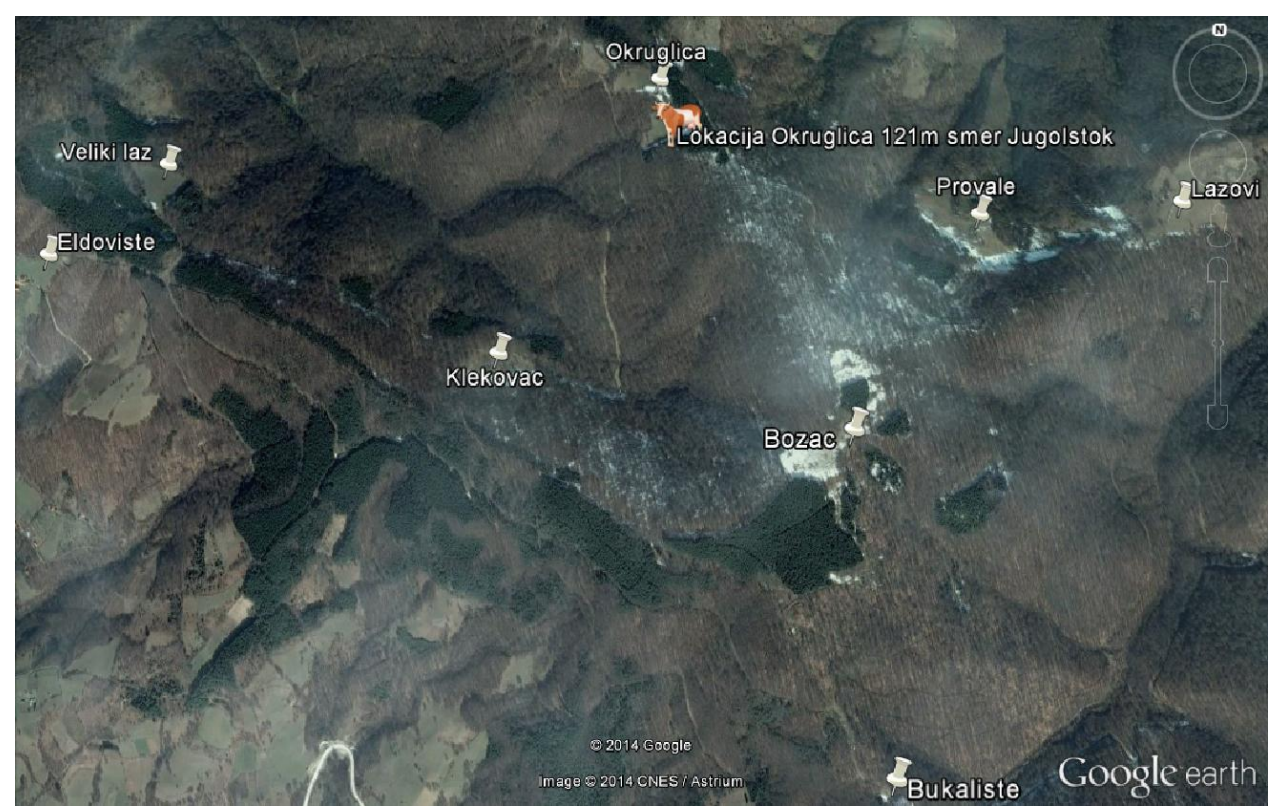

Figure 4. Cattle localization to closest reference point shown in Google Maps 


\section{Conclusion}

Device has been successfully used in small family farm near Ivanjica, in both operating modes. Device proves reliable and handy ally in locating and finding cattle, especially in poor weather conditions.

\section{Acknowledgement}

Work presented in this paper was funded by grant TR32043 for the period 2011-2014, by the Ministry of Education, Science and Technology Development of the Republic of Serbia.

\section{References}

Butler Z., Cork P., Peterson R., and Rus D., Dynamic Virtual Fences for Controlling Cows, in Proc. ISER, 2004, pp.513-522.

Ungar D., Henkin Z. Gutman, M., Dolev A., Genizi A., Ganskopp D. , Inference of Animal Activity From GPS Collar Data on Free-Ranging Cattle, Rangeland Ecology \& Management 58(3) May 2005

Telit Communications S.p: A. Telit GM862-GPS Modem Datasheet, 2009

Wikipedia, Web link: http://en.wikipedia.org/wiki/Point in polygon, accessed 1.12.2014

Lahanas M. and Karouzakis K., Fast generation of points inside triangulated objects obtained by cross-sectional counturs, Web link: http://www.mlahanas.de/CompGeom/Point_in_Poly.htm, accessed 1. 12.2014 


\title{
SMS PASTIR
}

- stručni rad -

\section{Uroš Pešović, Slađana Đurašević}

\author{
Fakultet tehničkih nauka Čačak, Univerzitet u Kragujevcu, Srbija
}

\section{Dušan Marković}

\author{
Agronomski fakultet Čačak, Univerzitet u Kragujevcu, Srbija
}

\section{Rezime}

SMS pastir je uređaj namenjen za lociranje objekata u otvorenom prostoru. Uređaj je prvenstveno namenjen za lociranje domaćih i divljih životinja, ali se može koristiti i za lociranje ljudi, prevoznih sredstava, modela na daljinsko upravljanje i drugih objekata koji mogu menjati svoj položaj. Uređaj je mobilan, malih dimenzija i poseduje baterijsko napajanje koje mu pruža višednevnu autonomiju. Uređaj se može koristiti u više režima rada, za lociranje objekata koje napuste definisan prostor ili lociranje objekata u slobodnom prostoru u odnosu na predefinisane referentne tačke. Uređaj za interakciju sa korisnikom koristi SMS poruke čime se od korisnika ne zahteva poznavanje rada na računaru, pristup internetu ili sl. Uređaj za svoj rad zahteva pokrivenost prostora $\mathrm{u}$ kome se koristi signalom mobilne telefonije. $\mathrm{S}$ obzirom da je pokrivenost teritorije Republike Srbije mrežom mobilne telefonije relativno visoka, obezbeđeni su dobri uslovi za korišćenje ovakvog uređaja u praksi.

Ključne reči: SMS, pastir, GPS, mobilni telefon, krdo. 